\title{
Padre Leonel Franca: articulações religiosas no Centro Dom Vital e na Liga Eleitoral Católica
}

\author{
Father Leonel Franca: religious articulations at the Dom Vital Center and the Catholic \\ Electoral League
}

\author{
Natália Cristina de Oliveira \\ Universidade Federal de Mato Grosso do Sul \\ natdeoliveir@gmail.com \\ Névio de Campos \\ Universidade Estadual de Ponta Grossa \\ ndoutorado@yahoo.com.br
}

\begin{abstract}
Resumo: O artigo discute a atuação do padre Leonel Franca, membro da Companhia de Jesus, como integrante do grupo intelectual católico do Rio de Janeiro, no segundo quartel do século XX. Ele, enquanto clérigo de confiança do cardeal/arcebispo dom Sebastião Leme, desenvolveu articulação de destaque na Igreja Católica. O Centro Dom Vital e a revista A Ordem consistiam em organizações atuantes em vários estratos sociais - com ideais alinhados aos princípios da Santa Sé auxiliando no processo de recatolização dos brasileiros, e tinham o padre Leonel Franca como assistente eclesiástico. A Liga Eleitoral Católica, outra expressão desses movimentos, contava com líderes da Igreja, incluindo o jesuíta, outros religiosos e agentes do laicato católico. Considerando esse contexto, o artigo coloca em relevo a atuação de padre Leonel Franca, destacando suas estratégias em prol da Ação Católica brasileira.
\end{abstract}

Palavras Chaves: Padre Leonel Franca. Ação Católica no Brasil. Igreja Católica.

\begin{abstract}
This article discusses the work of Father Leonel Franca, a member of the Society of Jesus, as a member of the Catholic intellectual group in Rio de Janeiro, in the second quarter of the 20th century. He, as a trusted cleric of archbishop Sebastião Leme, had a prominent articulation in the Catholic Church. The Centro Dom Vital and the magazine A Ordem consisted of organizations active in various social strata - with ideals aligned with the principles of the Holy See assisting in the process of recatolization of Brazilians and had Father Franca as an ecclesiastical assistant. The Liga Eleitoral Católica, another expression of these movements, had Church leaders, including the Jesuit, other religious and agents of the Catholic laity. Therefore, in this article, Father Franca's performance gains relevance, highlighting his strategies in favor of Brazilian Catholic Action.
\end{abstract}

Keywords: Father Leonel Franca. Catholic Action in Brazil. Catholic Church. 


\section{Introdução}

O século XIX ficou marcado, decisivamente, pela organização da Igreja Católica em âmbito brasileiro. O denominado século do ultramontanismo tem como principal marca o ápice do prestígio e da autonomia da liderança católica: o poder soberano e inquestionável do papa, consolidado pela encíclica Quanta Cura, promulgada em 1864 por Pio IX (1792-1878), e que trazia como apêndice o Syllabus Errorum, ou seja, a lista de erros. O documento condenava os ditos "erros modernos" como o racionalismo, o socialismo, o comunismo, a maçonaria e a própria separação entre Igreja e Estado. As medidas expressas por essa nova determinação repercutiram nos países europeus e, depois, na América Latina - incluindo o Brasil.

Havia a urgência da reorganização católica, proveniente, também, do combate múltiplo às denominações protestantes que passaram a oferecer serviços educacionais e assistenciais. Foi instaurada a "reconstrução institucional" da organização eclesiástica no período da Primeira República. Em países latino-americanos, tal como ocorreu no Brasil, "[...] a política expansionista da Santa Sé em fins do século XIX e começo do XX adotou uma clamorosa postura patrimonialista, sem abrir mão das metas de 'romanização' [...]' territorial. (MICELI, 2009: 19). Uma multiplicidade de investimentos passou a ser planejada no campo nacional, como, por exemplo, a aposta nos mais diversos níveis de ensino, para o qual, mais tarde, o padre jesuíta Leonel Edgard da Silveira Franca ${ }^{1}$ (1893-1948) contribuiu, seja com a reintrodução do ensino religioso nos currículos escolares, seja com a fundação e consolidação das Faculdades Católicas e Escola Politécnica na cidade do Rio de Janeiro, dois dos principais marcos de sua trajetória intelectual ${ }^{2}$.

Nessa ocasião, o papa Pio X (1835-1914) retomou documentos já emitidos pela Igreja Católica, reformulou-os e passou a divulgá-los como ferramentas de formação de grupos para que auxiliassem o clero. Campos (2010, p. 36) assevera que esse conjunto de encíclicas, cartas e documentos veiculados pela instituição em apoio aos domínios

\footnotetext{
1 Abordamos, neste texto, as articulações empreendidas por Leonel Edgard da Silveira Franca (18931948) - o Padre Leonel Franca - especificamente no Centro Dom Vital e na Liga Eleitoral Católica. No entanto, ressaltamos que o jesuíta desempenhou notória, e ativa, circulação/participação nas realizações religiosas, educacionais, sociais e culturais da elite eclesiástica brasileira do período expresso. (OLIVEIRA, 2018).

${ }^{2}$ Consideramos a concepção de trajetória com base na teoria do sociólogo Pierre Bourdieu. De acordo com esse autor, compreender uma trajetória intelectual consiste em "[...] descrever a série de posições sucessivamente ocupadas por um mesmo agente (ou um mesmo grupo), em um espaço ele próprio em devir e submetido a transformações incessantes." (BOURDIEU, 2016: 81).
} 
católicos “[...] determinava o papel do laicato católico no processo de reação ao laicismo, bem como na divulgação da doutrina da Igreja Católica". A elite intelectual católica orientava-se e organizava-se por esses documentos e, após isso, realizava o trabalho que lhes cabia: divulgar e propagar a fé católica. Com o trânsito políticoeclesiástico do então arcebispo do Rio de Janeiro, dom Joaquim Arcoverde (18501930), alguns favorecimentos tornam-se possíveis, como a consagração de todas as capitais brasileiras em sedes diocesanas. As conquistas religiosas continuam durante a permanência de seu sucessor, o arcebispo dom Sebastião Leme da Silveira Cintra (1882-1942).

Organizações como o Centro Dom Vital e congêneres, apoiadas nos moldes do catolicismo, tinham o intuito de contribuir com a Ação Católica brasileira na recatolização da sociedade. Miceli (2009) destaca que poucos clérigos se envolviam diretamente em partidos ou grupos parlamentares. Esse foi o caso do padre Leonel Franca que, apesar de sua influência e trânsito livre entre Igreja e Estado, morreu sem filiar-se a nenhum partido político. Considerando tal contexto, busca-se demonstrar, neste artigo, a forma como o padre Leonel Franca articulou os processos de conquistas católicas. Inicia-se com a discussão de sua atuação no Centro Dom Vital, ao desempenhar-se como um dos líderes religiosos e assistente eclesiástico. Em seguida, mostra-se a sua mediação e articulação na organização e desdobramento da Liga Eleitoral Católica no Brasil, bem como na orientação e direcionamento dos intelectuais católicos que se empenhavam em prol dos objetivos da Santa Sé.

\section{Padre Leonel Franca e o Centro Dom Vital: o assistente eclesiástico}

Com o Estado laico, a Igreja Católica andava por outros caminhos e aplicava seus domínios via implantações sociais. Esse mesmo desenvolvimento social foi o que apoiou e deu segurança para o fortalecimento da classe dirigente católica, por meio da atuação em instituições como a revista $A$ Ordem, o Centro Dom Vital e a Confederação Católica ${ }^{3}$. O período de separação entre Igreja e Estado não foi tão brusco, tampouco a afastou dos estratos sociais mais altos. Esses movimentos "[...] garantiram retorno quando a Igreja passou a operar numa posição de relevo no centro da vida política

\footnotetext{
3 A Confederação Católica, fundada em 1922, foi transformada, posteriormente, em Ação Católica Brasileira.
} 
nacional ao longo das décadas de 1930 e 1940.” (MICELI, 2009: 161).

Imersas nesse contexto é que, em defesa dos interesses religiosos, as elites intelectuais começaram a se mobilizar em favor da Igreja Católica. Como afirmado por Rodrigues (2005), nessa conjuntura a Igreja não tinha alternativas, mas se agarrava à estratégia de autodefesa, para isso reforçava seu direcionamento tradicionalista e elitista e firmava-se conservadora como meio de sobrevivência. O posicionamento da Santa Sé orientava a linha da Carta Pastoral (1916) de dom Sebastião Leme, recém-nomeado bispo da então arquidiocese de Olinda. Trilhava com o mesmo espírito combativo e concepção política de que a Igreja não deveria lutar com o Estado, mas, sim, evitar desgastes e procurar se destacar por meio da intelectualidade. Nesse mesmo rol de acontecimentos é que duas organizações foram empreendidas por Jackson de Figueiredo.

Jackson de Figueiredo Martins (1891-1928), advogado dedicado à política e ao jornalismo, intelectual católico, criou a revista A Ordem, em 1921 - nome sugestivo concernente ao seu objetivo. O periódico foi um dos responsáveis e mais utilizados para a divulgação das ações da Liga Católica em favor da doutrinação dos leigos à religiosidade cristã. Em 1922 foi inaugurado o Centro Dom Vital ${ }^{4}$, que recebeu o nome do falecido bispo de Olinda ${ }^{5}$, um dos principais combatentes na "Questão Religiosa". O fundador, sergipano e convertido, Jackson de Figueiredo, era definido como:

[...] autoritário, impetuoso e impaciente, ou seja, o contraponto da figura de Dom Sebastião Leme, comumente adjetivado como sereno no trato das coisas e das pessoas. Jackson de Figueiredo desejava inicialmente montar um partido político católico, a fim de privilegiar ações diretas no combate ao que chamou de 'desordens revolucionárias'; por ele caracterizadas como um ambiente de insatisfação e de mobilização na sociedade civil em que eram buscadas novas alternativas político-sociais. Nesse quadro, ficou conhecido por sua oposição ao liberalismo, ao comunismo e, mesmo, por seu combate ao tenentismo. (SKALISNKI JUNIOR, 2015: 32).

Embora essa fosse a ideia inicial de Jackson de Figueiredo, o arcebispo dom

\footnotetext{
${ }^{4}$ Azzi (2003) aponta como fundadores, de primeira hora, do Centro: Jackson de Figueiredo (presidente); Hamilton Nogueira (vice-presidente); Perilo Gomes (secretário); Jônatas Serrano e Tasso da Silveira. E, num segundo momento, Sobral Pinto, Alceu Amoroso Lima, Everardo Backheuser e Gustavo Corção.

5 Dom Vital, bispo de Olinda (1871-1877), antecessor de dom Sebastião Leme. Foi uma das principais figuras dos setores conservadores da Igreja Católica no Brasil a se envolver energicamente no conflito que ficou conhecido como a "Questão Religiosa”, por volta de 1873-1875.
} 
Leme interferiu - no que diz respeito à criação de um partido político - e o direcionou para outros caminhos. O arcebispo o apoiou na criação dos dois órgãos citados, que foram as maiores representações da reação católica, por meio laico, instauradas na sociedade. A revista A Ordem e o Centro Dom Vital "[...] surgem num contexto social que tende a adotar uma cosmovisão cada vez mais agnóstica. A luta que a inteligência católica trava é no sentido de legitimar-se perante a sociedade, combatendo seus erros políticos e religiosos.” (VELLOSO, 1978: 120-121 apud RODRIGUES, 2005: 140).

Com o apoio de dom Leme, o Centro preocupava-se em repensar o catolicismo no país e reorganizar estratégias para sua propagação. Um dos objetivos era o de seguir as diretrizes da Santa Sé em reação aos movimentos das tendências liberais, positivistas e socialistas. Os fundamentos da revista eram sólidos, tinham como referência “[...] Leão XIII e seu projeto restaurador da unidade da Igreja Universal em meio ao conturbado final de século XIX [...]”, que, décadas depois, foi reerguido por Pio XI, e serviram como incentivo aos intelectuais, para mediar as discussões religiosas e das ciências, num início de século que pedia racionalidade. (CASALI, 1995: 120).

Rodrigues (2005) assevera que os integrantes destas organizações tinham como intuito exercer a função de intelectuais na missão de evaporar a crise em que o país se encontrava, na medida que atribuíam a ela sentido espiritual. Essas instituições serviam, praticamente, como extensão da Igreja Católica. Era a intelligentsia agindo sobre a camada leiga em prol do direcionamento social e cultural religioso. Foram, ainda, responsáveis por grandes retiros espirituais, encontros entre a massa intelectual e líderes da Igreja Católica no Brasil, apoiavam a Ação Universitária Católica - que mobilizava estudantes das grandes cidades - promoviam eventos em centros universitários e editoras católicas ou com muita afinidade à doutrina cristã. (MICELI, 2001).

A criação da revista $A$ Ordem despertou o interesse do padre Leonel Franca, afinal, um dos propósitos do periódico era divulgar as ideias católicas e o formato social desejado e incentivado por ela, além do apoio incondicional de dom Leme aos vitalistas - termo cunhado por Arduini (2014) para denominar os integrantes do Centro Dom Vital. Além disso, o jesuíta costumeiramente trocava correspondência com Jackson de Figueiredo, de quem era grande amigo desde os tempos em que estudara em Roma, tratando dos mais diversos assuntos. Falavam tanto da vida pessoal como das preocupações que tinham pelo país e como poderiam utilizar o Centro Dom Vital e a revista A Ordem como reparadores dessas questões. Em carta do dia 20 de fevereiro de 1923, Jackson de Figueiredo escreve: 
Meu querido amigo, Padre Leonel Franca

Ao voltar de uma longa e interessantíssima viagem pelos mais remotos sertões paulistas, encontrei sua bondosa carta de 18 do 01 e os seus favores ao Centro D. Vital. Muito obrigado por tudo. Continuo com a minha saúde um pouco alterada, apesar de ter feito muito bem a viagem a que acima me refiro. Não lhe quero falar das difficuldades que vamos vencendo por aqui,

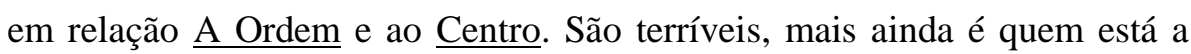
frente dele. Porque a péssima educação que tive e o péssimo temperamento que me cabe dominar, são talvez os piores elementos com que luto [...]. Sei que não são poucas as pessoas que oram por mim, [...] ai me vem a esperança de que você não me abandonará.

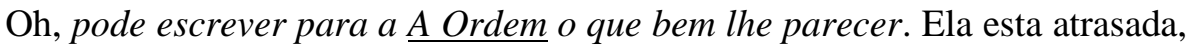
mas vou ver se a ponho em ordem dando três números de uma só vez. O que lhe parecer, já lhe disse. Mas se quiser organizar a serviço bibliographico de que me fala será excelente [...]. (FIGUEIREDO, 1923, grifo do autor. In: Arquivo da Província dos jesuítas no Brasil).

Notamos que o padre Leonel Franca nutria uma boa relação com o Centro Dom Vital, os laços do jesuíta com a organização já estavam atados. Jackson de Figueiredo contava com o apoio pessoal e espiritual dele, para resolução de suas questões, além dos conselhos e apoio amigo. Assumia ser alguém difícil, mas não se esquecia de que sua prioridade, naquele momento, seria o investimento em suas instituições. Ressaltamos a abertura e liberdade que Jackson de Figueiredo apresentava em relação ao padre Leonel Franca para escrever e divulgar o que bem entendesse no periódico. Fica nítido a proximidade que o jesuíta possuía nas publicações da revista. O excerto dessa correspondência confirma um dos pontos que levantamos nesta análise: o trânsito livre nos âmbitos políticos e culturais da sociedade carioca. Se a função d'A Ordem era propagar a fé cristã católica aos leigos, era por meio da persuasão literária que o jesuíta a atingiria. Jackson de Figueiredo encerra a referida carta despedindo-se e perguntando quando o padre retornaria ao Brasil para terem novas conversas sobre o estado religioso da sociedade.

Ao analisarmos o envolvimento de padre Leonel Franca, bem como sua relação com Jackson de Figueiredo, destacamos o espaço social que é definido pelos seus agentes, ou grupos, que o escolhem de acordo com seus interesses. Os agentes, por sua vez, posicionam-se nesse espaço pelo seu capital - o volume, em si - e, depois, pela 
composição deste capital. (BONNEWITZ, 2003). O jesuíta, nesses termos, representa essa afirmação. O integrante da Companhia de Jesus, na ocasião já conhecido por algumas de suas publicações, possuía noções precisas sobre a Igreja e exercia intenso domínio discursivo em defesa do catolicismo. (ARDUINI, 2014). As relações nos espaços sociais pelos quais transitava já estavam seladas e sua participação em diversos setores começava por intermédio de sua articulação social, principalmente em periódicos e meios de divulgação ágeis. As revistas, por exemplo,

[...] conferem uma estrutura ao campo intelectual por meio de forças antagônicas de adesão - pelas amizades que as subtendem, as fidelidades que arrebanham e a influência que exercem - e de exclusão - pelas posições tomadas, os debates suscitados, e as cisões - advindas. Ao mesmo tempo que um observatório de primeiro plano da sociabilidade de microcosmos intelectuais, elas são aliás um lugar precioso para a análise do movimento das ideias. Em suma, uma revista é antes de tudo um lugar de fermentação intelectual e de relação afetiva, ao mesmo tempo viveiro e espaço de sociabilidade, e pode ser, entre outras abordagens, estudada nesta dupla dimensão. (SIRINELLI, 2003: 249).

A Ordem evidencia, nesse contexto, um esforço tamanho para promover seu ideário religioso e reproduzir, por meio de suas publicações, os princípios católicos do século XX. A doutrina e o posicionamento político da Igreja foram ressaltados a fim de incentivar a sociedade civil a recuperar o prestígio católico junto ao governo. Essa representatividade pretendia atingir dos mais altos aos mais baixos estratos sociais. Casali (1995: 120) classificou essa revista, cronologicamente, em três fases, sendo:

a) a primeira fase engloba os oito primeiros anos (1921-1928), em que a Revista funcionou sob orientação e direção de Jackson de Figueiredo, até a sua morte;

b) a segunda fase compreende o período sob direção e orientação de Alceu Amoroso Lima: de 1928 até 1934 (Assembléia Nacional Constituinte);

c) a terceira fase se estende de 1934 até 1941 (data de instalação e início dos cursos das "Faculdades Católicas", no Rio).

É possível afirmar que o padre Leonel Franca atuou, de forma tenaz, em todas as fases do Centro e d'A Ordem. Foi consagrado líder religioso e orientador espiritual dos 
mais altos posicionamentos da liderança de ambas as organizações. Como assistente eclesiástico, organizava suas conferências e trabalhava todos os temas em forma de palestras. A primeira temporalidade do periódico, segundo classificação de Casali (1995), diz respeito às publicações mensais com um dualismo no que tange às relações do homem material e homem espiritual. Em praticamente todos os números há algo que ressalta a figura de dom Leme por sua combatividade e inteligência cristã, demonstrando a forma como o religioso pode, e deve, sobressair às realizações materiais. (CASALI, 1995). Sua Carta Pastoral de 1916 é mencionada em todos os artigos que falam sobre o projeto da restauração católica.

No número referente aos objetivos do Centro Dom Vital destacam-se:

[...] a criação de uma grande biblioteca católica e um serviço de informações bibliográficas e a edição de uma coleção de livros de apologética em geral, assim como de todo gênero de literatura que possa servir aos interesses da Igreja e da Pátria Brasileira. [...] O Centro Dom Vital (é) uma Sociedade que se propõe única e exclusivamente a ajudar o Episcopado Brasileiro na obra da recatolização de nossa intelectualidade. (A ORDEM, vol. 1, n.10, maio, 1922, grifo nosso).

A participação intensa do padre Leonel Franca fica exposta quando um de seus objetivos é ajudar o episcopado brasileiro na recatolização da intelectualidade. Isso o caracteriza como intelectual dominante, que por sua vez se diferencia dos outros por manter concentração acumulada de capital dos mais variados tipos. Os capitais, sejam eles cultural, simbólico ou econômico, são definidores e responsáveis pelas legitimações - ou não - do sujeito no mundo social. (BOURDIEU, 2012). Por outo lado, o volume de número 11 da revista apresenta a aprovação e a recomendação de dom Leme em relação a essa organização:

A fundação do Centro D. Vital é um acontecimento de grande alcance religioso e social para o Brasil. Pedindo a N. Senhor que abençoe os esforços do Dr. Jackson de Figueiredo, o iniciador dessa obra, aprovamos os seus estatutos. A todos os católicos, principalmente aos que se interessem pela restauração espiritual de nossos intelectuais, recomendamos o Centro D. Vital. Assinado: D. Sebastião Leme (A Ordem, 1922: 161, grifo nosso).

A comissão organizadora e editorial do periódico sempre ressalta e veicula o 
fato de A Ordem ter sido criada para auxiliar na militância católica. No entanto, a princípio, exclui a possibilidade de estar vinculada à formação de um partido católico que havia, naquele momento, sido defendida. Ainda assim, nos contatos frequentes entre Jackson de Figueiredo e o padre Leonel Franca, o líder do Centro Dom Vital escreve, no dia 25 de fevereiro de 1924: “[...] Sai do Rio dia 10, em missão política de confiança do Presid. da Republica, a ver o que era possível fazer em nome da paz, na luta que ora divide [...] Sergipe, meu Estado Natal”. Destacamos a relação entre Jackson de Figueiredo e o presidente da República, Artur Bernardes - contato essencial para as futuras conquistas do padre Leonel Franca em prol da Igreja. Em 26 de junho do mesmo ano, após a publicação de A Igreja, a Reforma e a Civilização (1923), o jesuíta recebe a seguinte correspondência:

[...] O S. nada tem que me agradecer relativamente ao que pude desejar ao seu livro, [...]. Vou indagar se o "Jornal O Commércio" deu nota della porque se não deu vou pedir ao Felipe para confiar-me a empreitada.

Devo dizer que a sua obra está fazendo um bem extraordinário ao paiz, e posso falar-lhe com autoridade no assunto, pelo simples motivo que não creio haja quem mantenha correspondência mais leveza, mais complexa do que a que teve. $[\ldots]$

Pois avalie que o Centro já offereceu para mais de 30 exemplares de sua obra. O que era necessário eu fiz, fazer della uma edição propriamente popular [...]. (FIGUEIREDO, 1924. In: Arquivo da Província dos jesuítas no Brasil).

Nessa passagem podemos observar o incentivo à divulgação da obra do padre Leonel Franca. Jackson de Figueiredo enaltece o escrito e afirma que ficará responsável pela crítica em um dos periódicos de maior circulação na sociedade carioca. Em tempo, afirma que a divulgação acontecia naturalmente e com sua ajuda, já que estava distribuindo exemplares. Ao publicar esse livro, além da defesa à Santa Sé, o jesuíta demonstrava o posicionamento "unificado" de toda a Igreja contra as críticas de caráter protestante. Bourdieu (2004, p. 102) aponta que o uso da escrita é uma das principais formas de representação e que é uma forma de organizar pensamentos sociais que, embora de forma aleatória, em muitas ocasiões, já estão difusos na sociedade, pois um “[...] autor no verdadeiro sentido é alguém que torna públicas coisas que - todo mundo percebia confusamente; alguém que possui uma capacidade especial - a de publicar o 
implícito, o tácito -, alguém que realiza um verdadeiro trabalho de criação".

O jesuíta iniciou, com esse livro, sua produção polemista na sociedade brasileira. A identificação dos vitalistas (e não somente de Jackson de Figueiredo) com o padre foi rápida, principalmente porque levavam em comum uma preocupação social com a escrita. Arduini (2014: 34) pondera que, de acordo com a produção bibliográfica do grupo, era possível perceber "[...] a presença maciça de manuais didáticos e os de cunho histórico-biográfico entre o conjunto de livros vendidos [...]. Outro grande gênero de sucesso no período, o romance, não teve nenhum grande representante do grupo". Nesse sentido, o principal ponto de argumentação dos integrantes foi social, e não apenas literário.

Com a morte de Jackson de Figueiredo, em 1928, Alceu Amoroso Lima foi eleito presidente do Centro. Com a mudança da liderança, outras questões foram alteradas, como, por exemplo, o perfil do grupo e o caráter da revista. Dom Leme, ao demonstrar sua afeição e pesar pela partida de seu escudeiro, escreve em edição d'A Ordem "[...] entre a Igreja e qualquer outra cousa, fosse o que fosse, ele preferia e preferiria sempre a Igreja. Erraria grosseiramente quem o julgasse catholico, por conveniência, oportunismo, interesses ou vaidades do momento"; e completa dizendo ser "[...] preciso que os intellectuaes brasileiros conheçam a verdade e gozem a ventura do amor e serviço de Jesus Christo!” (LEME, A Ordem, 1929: 01). O padre Leonel Franca, na mesma edição, onde vários intelectuais se posicionam, lamenta que com “[...] o desaparecimento de Jackson de Figueiredo acaba de extinguir-se no firmamento da Igreja brasileira, uma das estrelas de mais puro fulgir [...]." (FRANCA, A Ordem, 1929: 333). Com as mensagens pesarosas e inspiradoras (incentivando outros fieis a seguir o caminho do líder), o Centro e a revista iniciam um novo momento. O discurso do periódico, agora, passaria muito mais a seguir uma linha religiosa, filosófica e cultural do que política, como antes.

Azzi (2003: 13) defende a ideia de que o envolvimento político, assumido por Jackson de Figueiredo, reagia fortemente contra as pretensões revolucionárias do movimento tenentista. Embora seu primeiro projeto de criação de um partido político não tivesse sido implantado, continuava-se articulando nesse campo. E “[...] mantinhase coerente com a própria orientação da hierarquia eclesiástica. Conforme o discurso desse líder católico, tratava-se da defesa da ordem contra a anarquia militar e social".

Com 80 associados, em 1929, os membros da diretoria alugaram um apartamento e instalaram uma biblioteca - que foi arrendada pela viúva de Jackson de 
Figueiredo. Com anonimato, conseguiram apoio para manter a Livraria Católica e atingiram um número de 1.000 assinantes para colaborar com A Ordem. No Centro, continuavam as atividades:

[...] reuniões semanais das quartas-feiras, realizadas com edificante regularidade. Iam primeiro à Igreja de N. Senhora do Parto, e ali, recolhidos, na abençoada penumbra, rezavam o terço pela conversão de nossos homens de letras. [...] terminada a oração, dirigiam-se para a sede, onde se ouvia uma conferência sobre Filosofia, Sociologia ou outro assunto relacionado com a religião. (D’ELBOUX, 1953: 176).

As reuniões das últimas sextas-feiras de cada mês eram presididas pelo padre Leonel Franca e aconteciam no Colégio Santo Inácio - do qual era diretor. Com o passar do tempo, aumentou o número de integrantes e o total de envolvidos nas reuniões chegava a 200 homens. (D’ELBOUX, 1953). Notamos a preocupação empreendida aos "homens de letras" - contando que os intelectuais, por meio de suas ações, é que auxiliariam na resolução de todas as necessidades do laicato católico.

Sergio Miceli (1979), na obra Intelectuais e classe dirigente no Brasil: 19201945, afirma que os intelectuais, após a década de 1930, seduzidos pelo emprego público, passaram a apoiar o governo de acordo com seu posicionamento social. Além disso, aqueles que encontravam mais benefícios continuariam com o apoio no interesse de não serem afastados das classes dirigentes, tendo-as como produto. Ao contrariar esta tese, o sociólogo francês Daniel Pécaut (1990) defende que as conveniências oportunizadas pelo Estado não foram o único motor que moveu essa necessidade, e pensar dessa forma seria reducionismo, já que esses intelectuais poderiam, sim, estar imbuídos de um espírito de missão política. No entendimento de Miceli (1979), as principais camadas da classe dirigente:

[...] se empenharam em preservar e ampliar sua presença tanto no campo das instituições políticas como no campo da produção cultural, não resta dúvida de que as transformações ocorridas no mercado de bens culturais são indissociáveis da situação material e social das famílias da classe dirigente onde eram recrutadas as diversas categorias de intelectuais. (MICELI, 1979: $16)$.

No início da década de 1940, o posicionamento d'A Ordem não se mantém o 
mesmo, vê-se a necessidade de alteração da postura intelectual: passar de uma visão conservadora para uma visão mais liberal e democrática. A revista não fora criada para trabalhar em prol do Estado ou do governo, mas sim a favor de projetos exclusivamente da Igreja Católica. Esse ponto foi utilizado para justificar a imparcialidade em suas divulgações, no entanto claramente foi utilizado como arma de discurso político.

Ao final da década de 1930, muitos vitalistas alcançaram prestígio em publicar pela José Olympio - uma das editoras consagradas do período. Era, ainda, muito criticada por editar livros integralistas e de discursos autoritários, como os de Getúlio Vargas. Os leitores desses autores integralistas garantiam o sucesso e a veiculação das obras, além de um bom relacionamento com o Estado Novo. Amoroso Lima e o padre Leonel Franca publicaram pela editora José Olympio no final de 1930 e início de 1940, que, por sua vez, se adaptavam às leituras culturais e modificaram a compreensão de defesa do integralismo em 1930, bem como da liberdade de expressão para os comunistas em 1940. Ou seja, adaptavam-se às necessidades sociais e culturais, reinventavam-se de acordo com o imposto socialmente para estender os princípios católicos.

Franca e Amoroso Lima se destacaram desde sua formação, concluída no exterior; e Amoroso Lima alcançara nome importante como crítico literário, reconhecido dentro e fora da Igreja. Ele havia apoiado o modernismo desde antes da Semana de Arte de 22, interessando-se pela defesa do movimento $\grave{a}$ carioca, mais modesto em suas pretensões de renovação. Leonel Franca era um professor de secundário e palestrava sobre temas de interesse aos membros da elite mais devotos. Em ambos os casos, sua consagração provinha de funções ligadas à difusão da doutrina religiosa. (ARDUINI, 2014: 74).

Os dois intelectuais mantinham entre si uma relação próxima. Alceu Amoroso Lima, ao converter-se, alguns meses antes da morte de Jackson de Figueiredo, recebeu a primeira comunhão das mãos do padre Leonel Franca e a ele confiou o batismo de todos os seus filhos. As obras do jesuíta eram conhecidas por divulgar a união de preocupações apologéticas e científicas. Ao admirar esse mecanismo, referindo-se ao livro A Igreja, a Reforma e a Civilização (1923), que teve várias reedições, Alceu Amoroso Lima escreve: 


\begin{abstract}
Nossa civilização só pode nascer da aliança íntima e harmoniosa de um espírito científico positivo a um espírito religioso positivo. Um resolvendo os nossos problemas materiais básicos, o outro resolvendo os próprios fundamentos dos nossos problemas do espírito.
\end{abstract}

E por isso mesmo é que obras como esta do $\mathbf{P}$. Leonel, sendo um tributo admirável pela Verdade em si, são ao mesmo tempo um esforço necessário, de inteligência e bom senso, pela nossa verdade nacional. (LIMA, A ORDEM, 1922: 30-3, grifo nosso).

Alceu Amoroso Lima demonstra o imprescindível apoio do jesuíta no desenvolvimento da civilização. Diríamos, ainda, na incorporação, por meio da sociedade, aos ideários cristãos católicos. Estas afirmações contribuíram para a elevação da credibilidade do padre Leonel Franca não apenas junto àqueles leigos que acompanhavam as publicações d'A Ordem, mas também junto às lideranças católicas e governamentais. Sobre o cotejamento e a forma como Jackson, Alceu e Padre Franca se posicionavam em A Ordem, Arduini (2014: 126) avalia:

O papel de Franca é organizar os fundamentos filosóficos do grupo, enquanto Jackson (e, após sua morte, Amoroso Lima) vão traduzir o que significam estes fundamentos na seleção de quais obras artísticas e literárias merecem conhecimento e o apoio dos católicos, e quais são aquelas que não merecem. [...] Jackson de Figueiredo, o escritor mais prolífico sobre o tema da trinca, faz constantemente menção a Franca como o seu guia maior. Amoroso Lima não demonstra a mesma reverência e nem parece disposto a enfrentá-lo.

A análise de Arduini (2014) é pertinente na medida em que auxilia na compreensão da forma como o "trabalho" era distribuído nas edições. Entendemos que o padre Leonel Franca não desempenhava apenas a função de assistente eclesiástico ou de conferencista das reuniões do Centro Dom Vital, mas respondia também por posicionamentos, cotejamentos ou apresentações textuais ao longo das publicações. Arriscamos a dizer, ainda, que suas publicações bibliográficas poderiam ser exigências do grupo a fim de auxiliar na ampla divulgação dos princípios católicos. O Centro auxiliou no crescimento substancial do capital político da Igreja. Por meio de sua organização, houve um reforço da cosmovisão cristã, impulsionando a dominação religiosa católica na sociedade. Diante dessa enérgica tomada de posição, a liderança 
brasileira observava a força crescente da Igreja e reconhecia seu poder de estabilidade social.

O governo varguista e a Igreja Católica acordaram, nesse processo, um pacto informal de cooperação. A fim de “[...] reunir apoio ao seu regime, Vargas cultivou boas relações com a Igreja nacional", e um dos atos públicos protagonizado pelo presidente foi o episódio em que Getúlio “[...] compareceu com Dom Leme e outros bispos à inauguração da estátua do Cristo Redentor no morro do Corcovado, no Rio de Janeiro" (SERBIN, 2008: 99), um símbolo de que o catolicismo oficial - entre Igreja e Estado - estava reestabelecido, ainda que informalmente.

Notamos no seio d'A Ordem uma organização de sociabilidade muito bem engajada e estruturada. Sirinelli (2003) questiona se um microclima pode se transformar em zona cultural; compreendemos que no caso dos vitalistas isso foi possível. A revista, ou melhor dizendo, seu grupo, ditou regras num domínio estreito, mas que se espalhou por considerável parcela da sociedade de intelectuais católicos enquanto dirigentes. E para compreender os fios que perpassavam essas relações e davam estruturas sistematizadas ao projeto da Igreja Católica, faremos considerações acerca da Liga Eleitoral e Ação Católica - fruto dessas articulações e fatores determinantes para a prática do projeto do padre Leonel Franca.

\section{Padre Leonel Franca e a Liga Eleitoral Católica: o conselheiro religioso}

Em 1932, com o apoio dos intelectuais mobilizados pela causa da Igreja, o arcebispo dom Leme criou a Liga Eleitoral Católica (LEC) a fim de homogeneizar a orientação católica quanto à votação nas eleições. A LEC estimulava os católicos em quem votar, mas não os determinava diretamente. O princípio da Liga não era criar um partido ou expor-se com um posicionamento político. Pelo contrário, a avaliação da Igreja era a manutenção de posicionamento num local o mais reservado possível. Nas palavras de Alceu Amoroso Lima, o formato de orientação na escolha dos candidatos seria "[...] dirigir-se aos partidos políticos propondo à apreciação de todos eles um programa máximo de dez pontos e um mínimo de três. Conforme a receptividade desse programa, [...] a Liga faria suas opções, sugerindo em seguida ao eleitorado católico em quem deveria votar ou não.” (LIMA, 1973: 151).

Nesse sentido, o objetivo era "sugerir" candidatos, e não impô-los ou apoiá-los 
diretamente. Com a organização da LEC, a campanha eleitoral de 1933 mobilizou as mais altas camadas da intelligentsia para intervir, indiretamente, nos resultados. Segundo Azzi (2003: 25), a Liga passou por duas etapas distintas, sendo “[...] a primeira, de grande desenvolvimento, que se estende até 1937, e a segunda, menos significativa, de 1945 em diante". Alceu Amoroso Lima ressalta, ainda, que o ano de criação da LEC “[...] foi também marcado pela fundação do Instituto Católico de Estudos Superiores, base para a futura Universidade Católica, bem como por um ciclo de conferências do padre Leonel Franca no Colégio Santo Inácio, sob o patrocínio do Centro Dom Vital.” (LIMA, 2001: 110).

Tais ações auxiliam na mobilização do grupo para unificar forças com vistas à realização dos projetos católicos. Nessa conjuntura tratamos de um período em que o catolicismo aparece enquanto nome (católicos não praticantes) ou prática (católicos praticantes). (AZZI, 2008). Imbuídos do molde de democracia cristã e temendo os efeitos impactantes que poderiam se dar, entram em discussão, na LEC, as providências a serem tomadas. No entanto, isso foi feito com toda aparente "neutralidade" que a Igreja demonstrara, considerando que ela permaneceria nutrindo uma relação cordial com os detentores do poder - para isso deveriam ser extrapartidários e atuantes indiretos. Desse modo, “[...] os católicos não interviriam como facção nas lutas partidárias nem desgastariam a autoridade moral e política da única corporação da sociedade civil em condições de ombrear-se com o Estado.” (MICELI, 2001: 130).

A LEC divulgava diretrizes e posicionamentos da Igreja entre seus fiéis, a fim de angariar o maior número de votos possível para aqueles candidatos que estivessem afinados com o discurso do laicato católico. Como ressaltamos, a Liga não mantinha uma lista de candidatos, mas orientava para que aqueles que estivessem minimamente comprometidos com os ideais cristãos católicos pudessem estar entre os eleitos. Dom Leme, em 4 de fevereiro de 1932, faz uma consulta ao padre Leonel Franca - o que respalda nossas afirmações acerca de articulações do jesuíta nas decisões do rumo da Igreja Católica. O documento consistia na descrição de um plano para a criação da Liga Eleitoral Católica. É afixada a mensagem de que seja um arquivo confidencial, a fim de manter o sigilo na estruturação prévia da organização. Sinalizamos alguns destaques desse arquivo nominado Plano para a execução da Liga Eleitoral Catholica.

I- Não se trata de um partido político. Trata-se, apenas, de alistar o maior numero possível de eleitores que se compromettam: a) a exercer o direito de 
voto; b) a excerce-lo dentro das exigências da consciência catholica.

II- O funcionamento da Liga será obra de leigos, sem envolver a hierarchia da Igreja. [...]

V.- Para tudo que se refere a Liga, as autoridades ecclesiásticas têm na direcção homens de sua absoluta confiança. Só assim é que as Juntas poderão falar e agir em nome da Liga. [...]

VIII - Fixados e definitivamente escolhidos os nomes das juntas Estadoaes, pede-se aos Srs. Arcebispos determinem ao respectivo Secretario Geral que, em nome da junta telegrafe [...] o telegrama acompanhado de carta ou officio ao Secretario Geral da Junta Nacional, Dr. Alceu de Amoroso Lima.’[...]

Não se perca de vista, porem, que no intuito de "promover e defender o bem da religião, os catholicos de todo e qualquer partido devem procurar-se uns aos outros, para se falarem e ouvirem, e, sendo necessário, para mutuas concessoes”. (LEME, 1932. In: Arquivo da Província dos jesuítas no Brasil, grifos no original).

A carta do arcebispo dom Leme expõe os ideais da LEC e solicita que o padre Leonel Franca analise e contribua com o quadro em elaboração. A Liga foi tão fundamental que, embora não se possa avaliar precisamente, a maior parte das reivindicações na Constituinte de 1934 estava alinhada com os preceitos da Igreja Católica. (MICELI, 2001). Em seguida, no dia 23 de abril do mesmo ano, com o costume do arcebispo em consultar o jesuíta e vice-versa, segue outra carta:

Peço venia para lembrar que na reunião dos Srs. Arcebispos e Bispos, quando da inauguração do Monumento ao Christo Redemptor, como linha geral das atividades catholicas, no actual momento, foi excluída a formação de um partido, em favor da simples arregimentação eleitoral. Quanto á sua execução e detalhes, resolvido ficou que, acompanhando de perto os acontecimentos, eu escreveria a todos os Srs. Bispos, quando se me afigurasse oportuno. É o que ora venho fazer, apresentando a V. Excia., em caracter absolutamente reservado, o plano para a organização eleitoral dos catholicos. Desncessario me parece informar que já foi maduramente estudado por technicos. É de crer, pois, que, si todas as dioceses o aceitarem, conseguiremos bons resultados.

Como se bem vê V. Excia. não se trata de partido catholico, nem de um partido politico com orientações catholica. Trata-se, apenas, de propugnar inalienáveis direitos da Religião; pois, si é certo que problemas do mais alto 
interesse religioso vão ser discutidos e solucionados, a conclusão se impõe: por dever de fé, cumpre-nos cerrar fileiras.

Eis ahi, em poucas palavras, o objetivo da Liga. De suas vantagens praticas não preciso dizer.

$\mathrm{Si}$, fora e acima dos partidos, mobilizarmos e disciplinarmos um grande eleitorado, claro está que só os candidatos dos diferentes partidos, como os próprios partidos terão interesse em atender aos direitos da consciência catholica. Prevê-se até que alguns partidos, entrando em accordo com a Liga, adoptarão officialmente os pontos essenciaes de seu programa. Fica assim bem delineado o ponto em que os catholicos poêm a mira: em vez de um partido com candidatos próprios, querem influir nos programas e nos candidatos dos partidos existentes.

A organização da Liga, reflitamo-lo bem, não dispensa que nós, os arcebispos e bispos, directa e indirectamente, na medida de nossas forças, procuremos intervir junto dos leaders chefes e elementos prestigiosos das correntes politicas, no que diz - e só nisso - com a elaboração dos programas, em sua parte religiosa e na apresentação de candidatos, só do ponto de vista religioso.

Nos partidos militantes em cada Estado, há sempre catholicos de confiança e outros políticos de boa vontade que, bem orientados, poderão exercer benefica influencia.

Assentado que, independente da Liga, podemos contribuir valiosamente para a dupla finalidade de "bons programas" e "bons candidatos", voltemos à organização do eleitorado, reaffirmando o seu caracter de obra leiga. [...] Para norma de V. Excia. declaro que está nesse caso o Dr. Alceu de Amoroso Lima, que, como Secretario Geral da Junta Nacional, em assumptos da Liga - e só quando falar officialmente no caracter de secretario, não, portanto, em livros, revistas, conferencias e artigos de jornaes - representa o meu pensamento. [...]

Muito grato ficarei a V. Excia. pelos conselhos e luzes que me enviar com a resposta a esta carta.

Recommendado-me ás preces e bênçãos de V. Excia. Revma. seu Irmão e servidor muito amigo. (LEME, 1932. In: Arquivo da Província dos jesuítas no Brasil, grifos no original).

Na campanha de 1933 se inicia um forte trabalho para a divulgação de uma “democracia cristã". Por insegurança de os resultados políticos não favorecerem a 
organização católica, os religiosos criam essa Liga e direcionam um compromisso que será eficaz a eles e à política. Conforme Miceli (2001), a LEC mantinha o objetivo de “[...] divulgar as diretrizes e as tomadas de posição da Igreja entre os fiéis e canalizar os votos dos eleitores católicos em favor dos candidatos dos diferentes partidos que estivessem prontos a sustentar as posições católicas", principalmente pontos delicados como o divórcio, o ensino religioso nas escolas, a assistência eclesiástica às forças armada, entre outros. É sabido que, nesse sentido, “[...] grande parte das reivindicações constantes do programa católico foi incorporada à Constituição de 1934." (MICELI, 2001: 130).

A Igreja Católica, nesse período, mantém-se como na década de 1920, com a finalidade de recuperar seu status. Em troca disso, recebe apoio governamental para a criação de novas instituições, como foi o caso da Universidade Católica do Rio de Janeiro, fundada e consolidada pelo padre Leonel Franca. Para a conscientização ou direcionamento da população, o responsável pela paróquia deveria convocar os fiéis no domingo, pela manhã, para um missa e, na sequência, uma assembleia expondo as reivindicações católicas da LEC. No período da tarde do mesmo dia, o vigário deveria realizar uma “[...] reunião com os delegados de todas as capelas rurais cuja principal responsabilidade era percorrer todas as linhas, núcleos e povoações das colônias, para que cada um se inscrevesse como eleitor e fosse instruído sobre o dever do voto e sobre o programa da LEC.” (FAUSTO, 2007: 376).

Nas décadas de 1920 e 1930 a Igreja assume uma estratégia para defender-se do afastamento dos muros do governo. Nesse período a instituição vê-se obrigada a abraçar uma cosmovisão conservadora, tradicional e elitista, que, não obstante os tempos passados, agora reforça a formação de uma elite intelectual que atua como força para redirecionar os rumos religiosos do país. De acordo com Pécaut (1990: 73, grifos do autor), ao abordar o posicionamento do Estado e dos intelectuais como classe dirigente no que tange à cultura da política nacional, é possível afirmar que "[...] os intelectuais aderiram a uma 'ideologia de Estado', o Estado aderiu a uma ideologia da cultura, que era também a ideologia de um governo 'intelectual'. Estado e intelectuais estavam mutuamente comprometidos".

A elite responsável pela divulgação das informações de caráter intelectual se sobrepõe no Estado Novo, pois, além de estar em sua grande maioria ligada ao governo, controla suas informações e garante um domínio no que diz respeito à vida cultural no país. Sendo assim, o campo cultural fica comprometido, de forma que assegura o 
regime governamental e invalida as manifestações intelectuais que pudessem prejudicar os interesses nacionais.

É com esse espírito, vendo os intelectuais como solução para o direcionamento social das massas, que a LEC apresenta os efeitos nos resultados eleitorais e demonstra essa característica com a Constituição de 1934. O período fica marcado e expõe uma ligação entre Igreja e Estado. Dom Sebastião Leme, na mesma ocasião, traça diversas estratégias a fim de "recatolicizar" o Brasil. Empenhado no espírito religioso, Alceu Amoroso Lima relatou sua participação nesse processo e sinalizou que por meio da LEC e da Ação Católica seria possível contribuir “[...] na elaboração da nova Constituição. Éramos contra a laicidade do Estado. Defendíamos o princípio da distinção entre a Igreja e o Estado, não na base da dissociação, mas da cooperação. Este ponto de vista acabou prevalecendo na constituição de 1934.” (LIMA, 1973: 217).

A afirmação de Alceu Amoroso Lima foi também o princípio do padre Leonel Franca: estar a par das ações do Estado, sem concordar com todos os seus direcionamentos, mas de forma que sua contestação não fosse direta e ostensiva a ponto de danificar a relação que se havia, parcialmente, restaurado. Defendia-se a diferenciação entre Igreja e Estado, não para romperem relações, mas no que dizia respeito aos limites que competiam a cada um. Por meio da LEC, a "[...] Igreja conseguiu a promulgação da Constituição de 1934 em nome de Deus, a proibição do divórcio, uma legislação trabalhista pró-católica e o atendimento de reivindicações mais gerais do catolicismo, como o voto feminino e a liberdade de educação [...]." (SERBIN, 2008: 100).

Não há livros escritos pelo padre Leonel Franca - especificamente - sobre a LEC, mas há apoio e participação subliminar em todo o processo, como o jesuíta fez por toda a sua trajetória, afinal, “[...] o comportamento político dos intelectuais mereceria por si só um estudo.” (SIRINELLI, 2003: 230). Seria previsível, afinal, esperar essa reação de um padre que entrava e saía pelas portas da frente da presidência da República, sem nunca ter-se filiado a um partido político. É claro, as relações e os "pagamentos" pelos favores eram dados por meio de concessões e favores de interesses comuns. O padre Leonel Franca partilhou da preocupação de Amoroso Lima e dos vitalistas em conciliar a doutrina católica com o regime democrático. Houve, por exemplo, modificação “[...] nos meios de transmissão de suas palestras, que saem dos salões e corredores das organizações católicas para atingir um público amplo e difuso, através das ondas do rádio.” (ARDUINI, 2014: 177). Ratificamos essa afirmação não 
apenas pelos registros encontrados da participação do jesuíta nesse processo, mas pelas diversas sinalizações de sua indispensável frequência nos meios de atuação social e cultural. Recebe correspondência do dia 21 de maio de 1934 que dizia:

Ilmo Ver. Padre Leonel Franca

Tendo o Governo resolvido iniciar um serviço regular de propaganda do Brasil e dos interesses nacionais, tanto para fins de educação sistemática da nossa opinião publica, [...] temos o prazer de informar a V. S. que, a partir de quarta-feira, 23 do corrente, será irradiado diariamente o RADIO-JORNAL, cuja organisação e direção nos foi honrosamente confiada pelo Sr. Chefe do Governo Provisorio.

Entre os objetivos visados pela nova propaganda avulta a difusão de ideias sobre o progresso educativo e sobre os métodos pedagógicos que melhor concorram para elevar o nível cultural das massas da nossa população. Afim de tornar afetivos os propósitos do Governo nesse sentido, precisamos da colaboração dos que representam entre nós as expressões mais altas da cultura e competência no setor pedagógico.

Não podíamos, em tais circunstâncias, esquecer a contribuição valiosíssima que V.Sa. poderá prestar a obra tão patriótica e cujo alcance certamente será apreciado por V.S.[...]

Certo de que V. S. não recusará o seu concurso a um empreendimento em que poderá dar nova demonstração do seu espirito cívico e trazer mais uma útil cooperação à obra educativa de que depende o futuro da nossa Patria, agradecemos antecipadamente, subscrevendo-nos com os protestos do nosso alto apreço e consideração.

Salles...

Diretor Geral da Imprensa Nacional

(1932. In: Arquivo da Província dos jesuítas no Brasil).

Entre os temas enfatizados, a dualidade liberalismo e comunismo ilustrará grande parte dos debates travados n'A Ordem e nas ondas do rádio. Padre Leonel Franca, com um programa semanal, consegue uma repercussão ainda maior sobre o posicionamento a ser tomado pelos cristãos leigos daquele contexto. O ideal de um Estado forte "[...] presente tanto nas formulações do próprio Getúlio Vargas como de intelectuais ligados a seu governo, é também incorporada, em certa medida, pelos católicos, principalmente no que diz respeito à sua crítica ao liberalismo e ao 
comunismo.” (RODRIGUES, 2005: 140).

Em suma, até 1937, quando o regime autoritário eliminou os partidos e eleições, a LEC teve um poder considerável nos resultados dos processos eleitorais. Assentados nos princípios anticomunistas, a maioria dos candidatos apoiados por ela foram eleitos para a Assembleia Constituinte. E, como afirmado anteriormente, " [...] a constituição de 1934 incorporou as principais exigências da LEC, incluindo o apoio financeiro do Estado à Igreja, a proibição do divórcio e o reconhecimento do casamento religioso, a educação religiosa durante o período escolar e subsídios do Estado para as escolas católicas." (MAINWARING, 2004: 48). Até 1937, após a eliminação dos partidos e eleições, a LEC obteve prestígio e alcançou muitos de seus objetivos, e a Ação Católica deu continuidade a seus feitos.

Os movimentos da Ação Católica foram definidores para os rumos da Igreja brasileira. O papa Pio XI, que pontificou de 1922 a 1939, “[...] julgava os partidos políticos como sendo demasiadamente divisionistas, mas, mesmo assim, buscava alianças com o Estado para defender os interesses católicos.” (MAINWARING, 2004: 43). O papa apoiou dom Sebastião Leme em seus esforços para promover a restauração católica e compreendia que a Ação Católica brasileira seria fundamental neste processo.

Como resultado da constitucionalização do país, surgiu a Aliança Nacional Libertadora, o que dava mais força aos partidos de esquerda. A Restauração Católica, movimento também instituído por dom Sebastião Leme, em 1935, consistia num movimento de resposta àquela organização. Era composto por leigos que atuavam nas mais diversas camadas sociais e culturais, por meio das diretrizes de líderes eclesiásticos. O movimento da Ação Católica viera para realizar ações nos mais diversos setores da sociedade: religioso, educacional, moral, político. (AZZI, 2003).

A Ação Católica brasileira seguia a estrutura que o movimento tinha na França e na Itália - dependente da autoridade papal e dividida em masculino, feminino, adultos e jovens. O padre Leonel Franca era um entusiasta dessas organizações que se apresentavam em formato de grupos, associações, pastorais. Rodrigues (2005) relata que, antes de ser implantada no Brasil, ela já trazia a divulgação assertiva dessas ações em muitos outros países. A revista $A$ Ordem assumiu uma posição forte e firme em apoio à Ação Católica brasileira. Publicou, em 1936, uma carta do papa Pio XI enviada a dom Sebastião Leme e ao episcopado brasileiro com o título "Ação Católica Brasileira": 
Queremos [...] demonstrar uma vez o mais alto conceito que fazemos da colaboração que podem os leigos prestar ao Apostolado da Hierarquia, não só na defesa da verdade e da vida cristã [...] como também para que sejam em mãos de seus pastores, instrumentos eficazes de sempre maior progresso religioso e civil. [...] Nós estamos intimamente persuadidos de que a Ação Católica é uma grande graça de Nosso Senhor, quer em relação aos fiéis, que ele chama a colaborar mais de perto com hierarquia, quer em relação aos Bispos e Sacerdotes que, sempre, para mais larga e eficazmente desempenhar o seu sagrado ofício, encontrarão nas fileiras da Ação Católica almas generosas e prontas à coadjuvação decidida. (PIO XI, Papa. A Ordem, 1936: 5-6).

A Ação Católica era vista como uma obra fundamental à reação ao laicismo. Periódicos como A Ordem cumpriam a tarefa no processo de disseminação dos ideários católicos, considerando que o conservadorismo estava nas entranhas de todo o processo das ações. Em prol da Ação Católica, o padre Leonel Franca ofertava cursos e conferências em nome do Centro Dom Vital. Os temas discutidos na ocasião eram divórcio, família, vida, espiritualidade, morte e, principalmente, a psicologia da fé. Foram divulgados anúncios em todos os números d'A Ordem para que a adesão por parte dos leigos e seguidores fosse ampla.

Em um dos encartes da revista, na edição 96 de 1938, veiculava-se o periódico como órgão oficial da Ação Católica brasileira, apresentando Alceu Amoroso Lima como seu diretor e o padre Leonel Franca como orientador eclesiástico. O comercial, no tom de propaganda, apresentava ambos os integrantes como chamariz para aqueles interessados em compreender mais sobre essa organização. O jesuíta, em uma de suas conferências sobre o tema, reforça o motivo de existência e dos princípios da LEC:

Todo o brasileiro sente neste momento o seu quinhão de responsabilidade indeclinável. Aos indivíduos, como aos grupos sociais, que integram a comunidade nacional, incumbe a missão de trazer para o bem comum a sua colaboração sincera, as luzes de sua inteligência como a eficiência de sua atividade. A este imperativo da consciência cívica e da consciência religiosa deve a Liga Eleitora Católica a sua existência. (FRANCA, 1954: 115-116).

Por diferenciar o espiritual e o temporal, a Igreja não deveria se envolver diretamente na política, mas isso não a impedia de auxiliar nos rumos políticos de seus 
fiéis. Com o apoio maciço dos religiosos atuantes, todos os estados foram envolvidos nesse movimento, o país católico estava unido pela mesma causa. Ainda que os padres, diretamente, não estivessem em destaque, agiam de forma imprescindível para que o objetivo da Igreja fosse alcançado. Os objetivos estabelecidos pelo padre Leonel Franca na formação desses grupos foram inspirados nas idealizações do arcebispo dom Leme. E, na mesma inspiração dessas organizações, o jesuíta foi, aos poucos, integrando os mais diversos grupos.

\section{Considerações finais}

O padre Leonel Franca desempenhou, ao longo de sua trajetória, participações em importantes órgãos que demonstrassem apoio aos ideais católicos - o Centro Dom Vital foi umas das principais instituições nas realizações religiosas. $\mathrm{O}$ vínculo com essas associações deu ao intelectual a segurança fundamental para a consolidação de sua prezada e respeitada atuação junto à classe dirigente brasileira. Ao lado de líderes como o arcebispo dom Sebastião Leme, Jackson de Figueiredo, depois Alceu Amoroso Lima, ele desenvolveu conferências, conquistou conversões e conformou a organização de um projeto social católico que, embora tivesse como objetivo atingir a concepção do Estado, deixou de associar a Igreja a um determinado partido político.

O apoio resultante da consulta das fontes nos permite assegurar que a Liga Eleitoral Católica, elemento da Ação Católica, estava entre os principais instrumentos utilizados pela elite intelectual católica, principalmente concentrada entre os atuantes do Centro Dom Vital, para direcionar a população leiga ao caminho e aos princípios da Igreja, sem que isso fosse feito por adesão a um partido - ou grupo partidário específico. As estratégias empreendidas e desenvolvidas pelo padre Leonel Franca davam a esses movimentos a sustentação da Igreja e o apoio (in)direto dos mais importantes líderes da Igreja Católica no Brasil.

A atuação do intelectual padre Leonel Franca, um mediador da Igreja nos imperativos do governo Vargas, deixou marcas não apenas na sociedade cristã e leiga, mas, sobretudo, na elite intelectual católica do século XX. Além de confessor de figuras notórias da sociedade e conselheiro de uma geração, tinha um poder, ou um "peso", sobre a decisão de grandes intelectuais do período. Nesse sentido, na conjuntura em que 
viveu e atuou, suas articulações religiosas e políticas auxiliaram de forma imprescindível na recatolização da sociedade brasileira.

\section{Referências bibliográficas}

ARQUIVO DA PROVÍNCIA DOS JESUÍTAS NO BRASIL (2016), Cartas e anotações. Rio de Janeiro, consultas em mar.

A ORDEM (1922), Rio de Janeiro, v. 1, nº 11, p. 161, jun.

A ORDEM (1929), Rio de Janeiro, Edição In Memoriam - Jackson de Figueiredo (1891-1928).

A ORDEM (1936), Rio de Janeiro. PIO XI. Ação Católica Brasileira, p. 5-6.

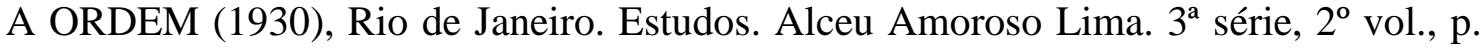
$30-31$.

A ORDEM (1938), Rio de Janeiro. GOMES, Perillo. Vicissitudes da vida internacional, p. 382, abr.

ARDUINI, Guilherme Ramalho (2014). Os soldados de Roma contra Moscou: a atuação do Centro Dom Vital no cenário político e cultural brasileiro (Rio de Janeiro, 1922-1948). 200 f. Tese (Doutorado em Sociologia) - Universidade de São Paulo, São Paulo.

AZZI, Riolando (2003). Os Pioneiros do Centro Dom Vital. Rio de Janeiro: EDUCAM.

AZZI, Riolando (2008). A Igreja Católica na formação da sociedade brasileira. Aparecida, SP: Editora Santuário.

BONNEWITZ, Patrice (2003). Primeiras lições sobre a sociologia de Pierre Bourdieu. Petrópolis: Vozes.

BOURDIEU, Pierre (2012). Escritos de Educação. 13. ed. Petrópolis, RJ: Vozes.

BOURDIEU, Pierre (2004). Coisas ditas; Tradução de Cássia R. da Silveira e Denise Moreno Pegorim; revisão técnica de Paula Montero. São Paulo: Brasiliense.

BOURDIEU, Pierre (2016). Razões práticas: sobre a teoria da ação. Campinas: Papirus.

CAMPOS, Névio de (2010). Intelectuais e igreja católica no Paraná: 1926 - 1938. Ponta Grossa: Editora UEPG.

CASALI, Alípio (1995). Elite intelectual e restauração da Igreja. Petrópolis, RJ: Vozes.

D’ELBOUX, Luiz Gonzaga da Silveira (1953). O padre Leonel Franca, S. J. Rio de Janeiro: Agir.

FAUSTO, Boris (2007). História Geral da Civilização Brasileira. O Brasil Republicano - Economia e cultura (1930-1964). 4. ed. Rio de Janeiro: Bertrand Brasil. T. 3. V. 11.

FRANCA, Leonel (1954). Alocuções e Artigos - Tomo I. Rio de Janeiro: Agir.

LIMA, Alceu Amoroso (1973). Memória Improvisadas. Petrópolis, RJ: Vozes.

LIMA, Alceu Amoroso (2001). Notas para a história do Centro Dom Vital / Introdução e comentários Riolando Azzi. Rio de Janeiro: EDUCAM; Paulinas.

MAINWARING, Scott (2004). Igreja Católica e Política no Brasil: 1916-1985. São Paulo: Brasiliense.

MICELI, Sergio (1979). Intelectuais e classe dirigente no Brasil (1930 - 1945). São Paulo: Difel.

MICELI, Sergio (2001). Intelectuais à brasileira. São Paulo: Companhia das Letras.

MICELI, Sergio (2009). A elite eclesiástica brasileira: 1890 - 1930. São Paulo: 
Companhia das Letras.

OLIVEIRA, Natália Cristina de (2018). Trajetória intelectual do jesuíta Leonel Franca: educação e catolicismo (1923-1948). 2018, 244 f. Tese (Doutorado em Educação) - Universidade Estadual de Ponta Grossa, Ponta Grossa, PR, 2018.

PÉCAUT, Daniel (1990). Os intelectuais e a política no Brasil: entre o povo e a nação. São Paulo: Ática.

RODRIGUES, Cândido Moreira (2005). A Ordem - uma revista de intelectuais católicos (1934-1945). Belo Horizonte: Autêntica; Fapesp.

SERBIN, Kenn (2008). Os Seminários: crise, experiências e síntese. In: MICELI, Sérgio. Intelectuais à brasileira. Tradução Laura Teixeira Motta. São Paulo: Companhia das Letras, p. 91-150.

SIRINELLI, Jean-François (2003). Os intelectuais. In: RÉMOND, René. Por uma história política. Rio de Janeiro: FGV, p. 231-269.

SKALINSKI JUNIOR, Oriomar (2015). Alceu Amoroso Lima e a renovação da pedagogia católica no Brasil (1928-1945): uma proposta de espírito católico e corpo secular - Curitiba. PR: CRV.

Artigo recebido em 18 de agosto de 2020.

Aprovado em 23 de outubro de 2020.

DOI: $10.12957 /$ intellectus.2020.53856 